\title{
A Technology for Designing a Vocational Module in Vocational Education
}

\author{
Elena Y. Zakirova ${ }^{1}$, Stanislav V. Obukhov ${ }^{2}$, Dmitry A. Krylov ${ }^{3}$, Anna B. Makarova ${ }^{4}$, Sergey G. Korotkov ${ }^{3}$, Ivan \\ S. Chupryakov ${ }^{3} \&$ Yevgeny B. Sivayev $^{3}$ \\ ${ }^{1}$ Kazan Aviation Technical College named after P. V. Dementiev, Kazan, Russia \\ ${ }^{2}$ Volga Branch of Volga State University of Technology, Volzhsk, Russia \\ ${ }^{3}$ Mari State University, Yoshkar-Ola, Russia \\ ${ }^{4}$ Nizhegorodsky Institute of Educational Development, Nizhny Novgorod, Russia \\ Correspondence: Elena Y. Zakirova, Kazan Aviation Technical College named after P. V. Dementiev, Kopylova \\ Street 2B, Kazan, 420036, Russia. E-mail: frau.levina2010@yandex.ru
}

Received: January 17, 2015 Accepted: January 29, 2015 Online Published: February 26, 2015

doi:10.5539/res.v7n3p327 URL: http://dx.doi.org/10.5539/res.v7n3p327

\begin{abstract}
The purpose of the article is aimed at improving the vocational training of students of technical vocational educational institutions in the field of organization and management of production processes. In the article the features of modern economic training of technical specialists are defined in the management and organization of production activity on the basis of modular competence-based approach. The article presents a technology for designing a vocational module that provides the organizational-management training of technicians in vocational education. The results of the research have a wide range of application for designing and implementing vocational modules for training vocational education students of not only technical, but also other specializations in corporate and post-professional education, and can be in demand by educators, researchers, customers of educational services.
\end{abstract}

Keywords: vocational education, modular competence-based approach, vocational module, designing, organizational-management training

\section{Introduction}

\subsection{Background}

The developing industry of Tatarstan Republic needs skilled workers and administrative staff of middle ranking. The introduction of new generation standards as one of the promising areas of vocational education modernization is urged to facilitate close cooperation between education and production, make the formation more practice-oriented, and the graduates - demanded in the labor market. Competitiveness of graduates of vocational educational institutions in the regional labor market is largely determined by the quality of their training (skill level), which can only be achieved in close integration of the educational process with modern hi-tech production (Tregubova et al, 2012; Korchagin, 2000, etc.). In the practice of vocational education, technical and economic training of specialists has been included for a long time, which is aimed at the acquisition of the economy foundations and the acquisition of technical and economic calculations, only in general terms relating to the organization and production management (Kal'nei, 1996; Simtsov, 2010).

But with the transition to a new stage of progress in science and technology, with the increasing complexity of technological processes and production, formation of market economy in Russia, the change in the enterprises' status, the contents were transformed and the number of the studied disciplines in the economy was increased. Such disciplines as general management, personnel management, quality management, strategic and financial management, logistics - appear and are rapidly developing, which requires reconsideration of the economic training content in vocational and technical education, the direction enhancement in the field of organization and production management. The organizational-management training is necessary to solve business problems in the workplace, manage workflow, and organize productive interaction between members of the working group. 


\subsection{Status of the Problem}

In modern pedagogical literature, devoted to vocational pedagogy, there are enough prerequisites to solve the designated issues at the scientific level: the problems of forming professional competencis are revealed (Baydenko, 2004; Zeer et al., 2005; Zimnya, 2006, etc.), the content, forms, methods and tools of vocational education designing technologies have been defined (Oleinikova, 2005; Novikov, 2008; Ibragimov, 2011; Safin \& Matukhin, 2012; Zyalaeva et al., 2012; Mukhametzyanova \& Shaikhutdinova, 2013, etc.) and the issues on modular technology of education (Choshanov, 1996; Batyshev, 1997; Ibragimov, 2008, etc.) have been considered. However, in teaching practice there is manifested inappropriateness of the technicians' organizational-management content training to the labor market, which confirms the need to change the direction of economic training from the technical-economic to the organizational-management. All this requires a change of the methodological and substantive foundations of the organizational-management training of technical students and their transfer to the basis of the modular competence-based approach, established by the Federal State Education Standard of Secondary Vocational Education.

\subsection{The Research Problem}

The transition from the knowledge-education paradigm to the competence-based one resulted in a change of standards of vocational education and actualized the implementation of the modular competence-based approach (Kochneva, 2010; Boytsova, 2011; Zakirova \& Levina, 2013, etc.). The organizational-management training, as part of vocational training, develops management skills: initiative, entrepreneurship, high social and industrial adaptation of graduates of technical professions. Thus, there is the need to develop the structure and content of the organizational-management training within a vocational module for training technicians in vocational education.

\section{Materials and methods}

\subsection{Problems of Transforming the Content of Vocational Education at the Present Stage}

With the development of market relations the content of many professions, including technical specializations, has undergone major changes, a number of professions turned out to be not in demand, and also there appeared many new professions. These changes are caused by the following reasons: changes in the organization of work due to the use of new technology, materials and technologies; reorientation of the demand for new skills; decline in demand for unskilled manual labor; decline of mass production; boundaries blurring between professions owing to the economy decentralization, the enterprises' withdrawal from rigid sectoral subordination and the development of quality management systems.

Modular technologies and the competence-based approach in teaching allow following the changes of the demand in the regional labor market and in a timely manner to adapt to the happening changes. The Federal educational standard of secondary vocational education at its core contains the competence-based approach to learning outcomes and the modular approach to the organization of the learning process that involves: empowerment of an educational institution in the formation of the content of the basic vocational educational program; strengthening the role of employers in the formation of the substantive, procedural and productive components of educational programs; formation of a system of continuing education, integration of primary and secondary vocational education; modernization of the material-technical base of vocational educational organizations; orientation of secondary vocational education to the regional labor market.

\subsection{Implementation of the Modular Competence-Based Approach in Vocational Education}

In the organization of educational process according to the basic vocational curricula, modular technologies are used, based on competencies, what gave an impetus to the development of a new approach in pedagogy - the modular competence-based.

The modular competence-based approach in vocational education - is a model for organizing the educational process, the aim of which is - to master general and vocational competencies through modular construction of the educational process, by providing flexibility of the substantive and procedural components through individualization of the learning process.

Modular technologies, based on competencies, have some fundamental differences from the technology of modular training, which consist in: the opportunity to articulate the effective training component, proceeding from the goals and objectives, that meet the needs of employers; the enhancement of personal activities importance of not only a teacher, but also of students, by increasing the hours of independent work; training the students for the real labor activity, for a specific workplace; growing confidence of the social partners in the educational institutions' performance results, due to bringing them to form the substantive and productive 
components of the learning process; the flexibility increase in the vocational training programs. In organizing the module, these elements provide a number of opportunities for a better formation of general and vocational competencies, namely: most fully to disclose the aspects of the students' future vocational activity, as much as possible to adapt them to productive activities; develop the creative potential of students and teachers. But the modular competence-based approach has a number of limitations related to how closely the relationship "education-production - science" is developed; what is the potential of students, their ability and readiness to develop vocational competencies (level of students' basic competence); up to what extent the teaching staff have mastered various procedures to transfer theoretical knowledge into practice (the level of the teaching employees' professionalism); the state of material-technical base of educational organizations, et cetera.

\subsection{Basics of Designing a Vocational Module}

By the functional features a module within the standards of the third generation is defined as a unit of the national curriculum in the specialization, which represents a set of academic disciplines that meet the qualifying characteristics and a set of general and vocational competencies needed for the development.

A key principle of learning, based on competencies, is to focus on results, aimed at the formation of the competencies that are relevant to the world of work and most effectively implemented in the form of modular programs. Each module consists of three components: the specification of the module; evaluation materials; educational materials. The modular technology basis - is a module, the logically complete fragment of educational material, created with a focus on the formation of competency.

The main learning methods used in the modular competence-based approach will be as follows: active learning methods (method of problem-based learning, advanced learning, solving production problems, et cetera); interactive teaching methods (business and role-playing games, immersion method, et cetera); independent work (scientific - research, analytical).

In the development of substantive and evaluative modular unit the following are taken into account in the aggregate: qualification characteristics, level of competencies development and control methods.

\section{Results}

\subsection{Features of Modern Economic Technical Training in Vocational Education}

It is established that at the present stage of modernization of the education system there has been a change of economic training in the direction of organizational-management disciplines, and this is also confirmed by our survey of employers (survey of regional enterprises' heads, a total of 27 people). The survey results showed that the employers preferred that technical students mastered not so much the technical-economic calculations (prime cost calculation, payroll, economic efficiency, et cetera), but the organizational-management activities (to be able to plan their work and the work of the small working groups, to plan a career, to competently monitor, et cetera). In such circumstances, the education tailored to the needs of enterprises becomes reasonably necessary. The organizational-management training in the pedagogy of vocational education should be seen as a process under control, which functions and is improving to meet the needs of professional activities, as well as the need to form a high-level trainees' readiness to perform their professional functions.

Analyzing the set of competencies, knowledge and skills required to be mastered in the study of the organizational-management module according to the education standard for technical professions (in particular, the training areas "Aviation and rocket-space technology"), we see that there has been collected data on such disciplines as "Management", "Legal framework of professional activity", "Economics", "Logistics", "Organization of labor", "Production preparation", "Organization of production management", "Marketing", "Labor protection", "Paperwork." The list of these disciplines allows us to say that the students not only master the organizational and managerial disciplines, but also get prepared for entrepreneurial activity within their specialization.

\subsection{The Technology for Elaborating a Vocational Module on the Example of the Organizational-Management Disciplines}

The technology for developing a vocational module is formed in several stages, on each of which we carried out certain actions (Table 1).

Based on the identified characteristics, the designing of the organizational-management module has been carried out. This research took into account the possibility of pedagogical designing at certain levels, depending on the requirements to the result and the presentation forms of the product: the conceptual, substantive, procedural levels. 
Table 1. The technology for designing an organizational-management module for training technical students

\begin{tabular}{|c|c|c|}
\hline Stages & Components & Actions \\
\hline \multirow{8}{*}{ 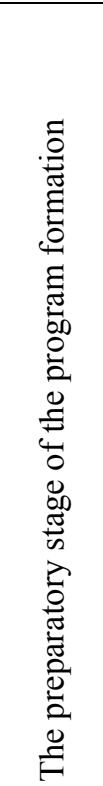 } & \multirow{6}{*}{$\begin{array}{l}\text { Problem } \\
\text { identification }\end{array}$} & 1. Analysis of the State Educational Standard and the Federal State Educational \\
\hline & & 2. Analysis of the requirements of the external environment - the social mandate. \\
\hline & & 3. Comparison of the obtained results - identification of the problem. \\
\hline & & $\begin{array}{l}\text { 4. Based on the problem, the definition of the input (initial level of competence) and } \\
\text { output (level of competence, which should be reached by the students) specialization } \\
\text { profile. }\end{array}$ \\
\hline & & $\begin{array}{l}\text { 5. Evaluation of necessary resources, pedagogical conditions and the existing } \\
\text { restrictions for implementing the modular program. }\end{array}$ \\
\hline & & $\begin{array}{l}\text { 1. Definition of the strategic objectives for the organizational-management training } \\
\text { within the FSES, taking into account the requirements of the social partners. }\end{array}$ \\
\hline & $\begin{array}{l}\text { Formulation } \\
\text { goals }\end{array}$ & $\begin{array}{l}\text { 2. Determination of the private goals - learning objectives of a specific } \\
\text { organizational-management discipline, a management module. }\end{array}$ \\
\hline & $\begin{array}{l}\text { Defining the input } \\
\text { conditions }\end{array}$ & $\begin{array}{l}\text { Defining the minimum requirements to the competence of students, who are starting } \\
\text { to study the module (knowledge, skills, competencies mastered at school in } \\
\text { "Economics" discipline class) }\end{array}$ \\
\hline \multirow{11}{*}{ 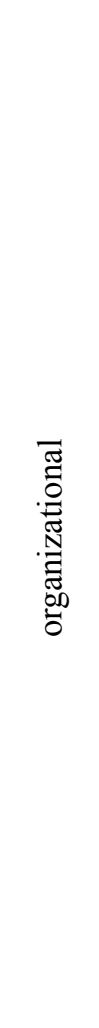 } & \multirow{3}{*}{$\begin{array}{l}\text { Defining the } \\
\text { organizational-pe } \\
\text { dagogical } \\
\text { conditions of } \\
\text { implementing the } \\
\text { module }\end{array}$} & $\begin{array}{l}\text { 1. Identification of external conditions: the presence of a well-functioning mechanism } \\
\text { of interaction "enterprise - educational organization of Secondary Vocational } \\
\text { Education" on the basis of parity. }\end{array}$ \\
\hline & & $\begin{array}{l}\text { 2. Identification of internal conditions: the formation of innovative educational space } \\
\text { within the vocational module on the basis of integration of modern forms, methods and } \\
\text { means of instruction. }\end{array}$ \\
\hline & & $\begin{array}{l}\text { 3. Identification of the initiating conditions: the presence of the diagnostic system of } \\
\text { formation of organizational and managerial skills. }\end{array}$ \\
\hline & \multirow{3}{*}{$\begin{array}{l}\text { Selection and } \\
\text { analysis of the } \\
\text { resource support } \\
\text { for the } \\
\text { implementation of } \\
\text { the module }\end{array}$} & $\begin{array}{l}\text { 1. Selection of ICT (computers, multimedia systems, interactive whiteboards, et } \\
\text { cetera) and software to transmit the educational information (basic and } \\
\text { supplementary). }\end{array}$ \\
\hline & & 2. Determination of the production practices base. \\
\hline & & 3. Selection of information sources. \\
\hline & \multirow[t]{2}{*}{$\begin{array}{l}\text { Designing } \\
\text { substantive } \\
\text { component }\end{array}$} & $\begin{array}{l}\text { 1. Selection, analysis and formation of the content by determining specific teaching } \\
\text { units (sections, topics, et cetera) and establishing a logical sequence of studying them. } \\
\text { The laying out of educational material into interdisciplinary courses, sections, topics, } \\
\text { considering the interdisciplinary connections. }\end{array}$ \\
\hline & & 2. Defining the models of knowledge in the module. \\
\hline & \multirow{3}{*}{$\begin{array}{l}\text { Designing } \\
\text { procedural } \\
\text { component }\end{array}$} & 1. Selection of methods and forms of training. \\
\hline & & 2. Selection of training technologies. \\
\hline & & 3. Selection of training resources. \\
\hline \multirow{3}{*}{ 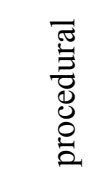 } & \multirow{3}{*}{$\begin{array}{l}\text { Designing } \\
\text { productive } \\
\text { component }\end{array}$} & 1. Definition of evaluation criteria. \\
\hline & & 2. Selection of methods, types and forms of control. \\
\hline & & 3. Definition of evaluation tools - creation of control and assessment tools database. \\
\hline $\begin{array}{l}\sum_{0}^{0} \\
\stackrel{0}{0} \\
\vdots \\
0\end{array}$ & $\begin{array}{l}\text { Designing the } \\
\text { passport of the } \\
\text { vocational module }\end{array}$ & $\begin{array}{l}\text { Accurate structuring of the material by the vocational module work program sections } \\
\text { in accordance with the established sequence. }\end{array}$ \\
\hline
\end{tabular}




\subsection{Methodological Support of the Organizational-Management Module}

There has been developed and implemented the methodological support for the organizational-management module in the educational process of the educational institutions of secondary vocational education, including the regulatory and educational documentation, training aids, test tools. This methodological support allows teachers to organize the educational process to meet the requirements of the new generation standards and employers, allows a student to learn better the training material. The composition of the educational and training material has been defined (guidance papers and instructions) for the most efficient organization of the educational process, as part of a modular competence-based technology for teaching the organizational-management disciplines, their structure has been worked out, the content, and the form of data submission. As part of the technology there have been developed and applied: 1) guidance papers: a set of lectures; supportive notes; a workbook; 2) guidelines for accomplishing a course-work and the economic part of the graduation project; for carrying out practical works, for industry-focused practical training (practice diary). Both traditional and electronic textbooks are used as educational literature.

Multimedia educational visual aids have been developed by sections and topics of the modular program, including tables, charts, graphs, photographs, clearly demonstrating the future professional activity in the field of production management at the primary workforce. The software has been formed as a set of computer programs necessary for the development of professional competencies. The necessary and sufficient set of modern learning tools has been determined for implementing the modular competence-based approach: electronic textbooks, multimedia complex, guidance papers. The author's testing tools have been elaborated for the organizational-management module. To test the theoretical knowledge the test tasks and written test papers of different levels of complexity are used. To test the skills - complex practical works are used, which result in making an administrative decision on a specific production situation, and to check the level of the competencies development - the industrial practice is used. An integrated level evaluation system of the competencies formation has been developed. In evaluating the competencies formation the three-level integrated evaluation system is used (introductory, reproductive, productive level).

\subsection{Testing the Organizational-Management Vocational Module}

Implementation of the organizational-management vocational module was carried out on the basis of the Kazan Aviation Technical College named after P. V. Dementiev and Taganrog Aviation College named after V.M. Petlyakov. The conditions of academic work in the control and experimental groups (except the experiment) were equalized. The initial levels of the organizational-management training in the experimental and control groups were identical - economic knowledge within the school curriculum.

The criteria of proficiency were defined by qualitative and quantitative progress indicators in the control and experimental groups (Figure 1).

For further experiment and comparative analysis the specialized practice and internship were taken, because the plans of these practices include questions on economic and management disciplines, in particular, the performance of the lowest management level supervisor's responsibilities by the student $-a$ foreman, a master, a technologist. During the industrial practice and internship the students of control and experimental groups had equal chances to approve themselves in the company for future employment in their field. The evaluation results of the student activities of experimental and control groups are shown in Table 2. 


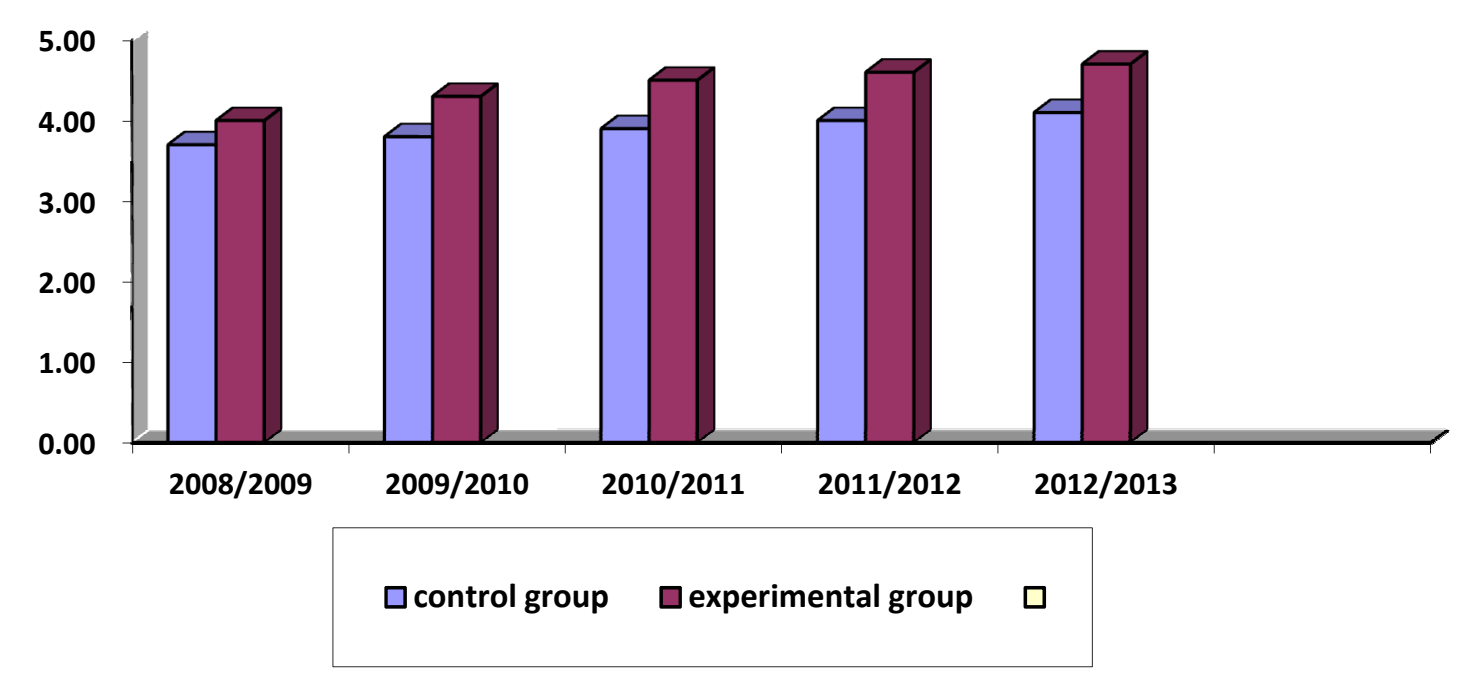

Figure 1. Dynamics of the average grade on the disciplines within the organizational-management training of students of control and experimental groups

Table 2. Results of defending the reports on the practice in the control and experimental groups

\begin{tabular}{|c|c|c|c|c|c|c|c|c|c|}
\hline \multirow[b]{2}{*}{ GROUP } & \multirow[b]{2}{*}{$\begin{array}{l}\text { all } \\
\text { (people) }\end{array}$} & \multicolumn{4}{|c|}{ Profile practice } & \multicolumn{4}{|c|}{ Traineeship } \\
\hline & & $\begin{array}{l}\text { "5" } \\
\text { (people) }\end{array}$ & $\begin{array}{l}\text { "4" } \\
\text { (people) }\end{array}$ & $\begin{array}{l}\text { "3" } \\
\text { (people) }\end{array}$ & $\begin{array}{l}\text { average } \\
\text { score }\end{array}$ & $\begin{array}{l}\text { "5" } \\
\text { (people) }\end{array}$ & $\begin{array}{l}\text { "4" } \\
\text { (people) }\end{array}$ & $\begin{array}{l}\text { "3" } \\
\text { (people) }\end{array}$ & $\begin{array}{l}\text { average } \\
\text { score }\end{array}$ \\
\hline \multicolumn{10}{|c|}{ 2008-2009 training period } \\
\hline $\begin{array}{l}\text { control } \\
\text { group . }\end{array}$ & 14 & 6 & 5 & 3 & 4.2 & 6 & 8 & 0 & 4.3 \\
\hline $\begin{array}{l}\text { experiment } \\
\text { group }\end{array}$ & 17 & 9 & 8 & 0 & 4.5 & 11 & 6 & 0 & 4.6 \\
\hline \multicolumn{10}{|c|}{$\begin{array}{l}\text { 2009-2010 training period } \\
\text { control }\end{array}$} \\
\hline $\begin{array}{l}\text { group } \\
160203\end{array}$ & 30 & 13 & 12 & 5 & 4.2 & 13 & 13 & 4 & 4.2 \\
\hline эксп. & 35 & 20 & 15 & 0 & 4.5 & 22 & 13 & 0 & 4.6 \\
\hline \multicolumn{10}{|c|}{$\begin{array}{l}\text { 2010-2011 training period } \\
\text { control }\end{array}$} \\
\hline $\begin{array}{l}\text { group } \\
\text { experiment }\end{array}$ & 24 & 11 & 10 & 3 & 4.3 & 11 & 12 & 1 & 4.1 \\
\hline group & 21 & 13 & 8 & 0 & 4.6 & 13 & 8 & 0 & 4.6 \\
\hline \multicolumn{10}{|c|}{$\begin{array}{l}\text { 2011-2012 training period } \\
\text { control }\end{array}$} \\
\hline $\begin{array}{l}\text { group } \\
\text { experiment }\end{array}$ & 22 & 10 & 10 & 2 & 4.3 & 10 & 12 & 0 & 4.2 \\
\hline group & 25 & 14 & 11 & 0 & 4.6 & 15 & 10 & 0 & 4.6 \\
\hline $\begin{array}{l}\text { 2012-2013 } \\
\text { control }\end{array}$ & ining peri & & & & & & & & \\
\hline group & 12 & 7 & 3 & 2 & 4.1 & 8 & 4 & 0 & 4.3 \\
\hline $\begin{array}{l}\text { experiment } \\
\text { group }\end{array}$ & 13 & 10 & 3 & 0 & 4.7 & 10 & 3 & 0 & 4.7 \\
\hline
\end{tabular}


Activity-based personal criteria of professional activities were determined by the indicators of employment and assigning of graduates to the basic enterprises. The result of the efficiency of any educational technology, including the technology for designing vocational modules, is a demand for graduates, trained by the vocational module program, on the labor market. On average, the employment of graduates at the basic enterprises from the experimental groups- $90.2 \%$, from the control groups - $44.7 \%$ (provided that the technology is considered effective if at least $70 \%$ of graduates of the experimental group find employment). The remaining $1.8 \%$ of the graduates of the experimental group entered the full-time department of higher educational institutions. Among $90.2 \%$ of the employed $19.3 \%$ continued their education according to their specialization in higher educational institutions in the full (intramural) and part-time (extramural) courses of study at the expense of the employer. In the control group only $11.6 \%$ of the employed at the basic enterprises continued education in their specialization field in intra-extramural form of study at the expense of the employer. This shows that the students of the experimental groups are more in demand by employers, all other things being equal. Enterprise assignment after one year of operation, in the experimental group $-91 \%$, in the control group $-59 \%$.

\section{Discussions}

The main purpose of developing the vocational module - is to provide basic enterprises with professionals whose level of training meets the needs of employers. The basis of readiness for professional work is determined by personal and active qualities of a technician in the organization and production management area.

From the analysis of the data presented in the tables, we can conclude that the figures in the experimental groups turned out to be statistically better, indicating that the technology developed by the authors for designing the organizational-management module for technical students - is effective. The use of the author's methodological support in the organizational-economic training of students of a vocational educational organization promotes optimization of the educational activity.

\section{Conclusions}

The proposed technology in the research for designing the vocational module, comprising the stages: preparatory (problem identification, formulation of objectives, definition of input conditions); organizational (definition of the org.- ped. conditions of implementing the module, selection and analysis of the resource support for implementing the module); procedural (designing the substantive, procedural and productive components); productive (designing the passport of the vocational module) - is efficient, has the versatility and can be used for designing the module of any orientation in vocational educational organizations. The application of the developed technology allows increasing the competitiveness of graduates of educational institutions.

\section{Acknowledgments}

The authors thank all participants of this study for their kind cooperation.

\section{References}

Batyshev, S. Y. (1997). Modular training (p. 59). Moscow Publisher Transservice.

Baydenko, V. I. (2004). Competence in vocational training. Journal of Higher education in Russia, 11, 4.

Boytsova, T. M. (2011). Module and competence approach in vocational education. Journal of Secondary vocational education, 11, 39 .

Choshanov, M. A. (1996). Flexible technology problem-modular education (p. 160). Moscow Publisher Education.

Ibragimov, G. I. (2008). New features lesson: Modular training. Journal of Education, 7, 211

Ibragimov, G. I. (2011). Innovative learning technologies in the conditions of implementation of the competency approach. Journal of Innovations in Education, $4,4$.

Kal'nei, V. A. (1996). Pedagogical bases of economic and technological training of youth: The dissertation of the doctor of pedagogical sciences (p. 398). Kazan.

Kochneva, E. N. (2010). Modular competence-based approach to professional education programs. Journal of Secondary vocational education, $10,38$.

Korchagin, E. A. (2000). Problems of training students SSUZ under standardization of education (p. 106). Kazan Publisher "Fort dialogue".

Mukhametzyanova, F. S., \& Shaikhutdinova, G. A. (2013). Modern educational strategies for training teachers in primary and secondary education (conceptual ideas, concepts, requirements GEF) (p. 54). Kazan Publishing house "Danis". 
Novikov, A. M. (2008). Post-industrial education (p. 136). Moscow Publisher "Egves".

Oleinikova, O. N. et al. (2005). Development of modular programs based on competences (p. 288). Moscow Publisher Alpha-M.

Safin, R. S. et al (2012). Innovative Entrepreneurship Education in continuing professional education. Kazan pedagogical journal, 5-6(95), 79.

Simtsov, O. V. (2010). Economic preparation Professional skills: Diagnostic results (p. 60). Bugulma Publisher "BUGULMA typography".

Tregubova, T. M. et al. (2012). Strategic priorities for the modernization of Russian professional education in the context of globalization and its integration: collective monograph (p. 152). Kazan publishing "Danis".

Zakirova, E. Y., \& Levina, E. Y. (2013). Development of modular competency approach in vocational education. European Social Science Journal, 9(3), 80.

Zeer, E. F., Pavlova, A. M., \& Symanyuk, E. E. (2005). The modernization of vocational education: Competence approach (p. 216). Moscow Publisher MPSI.

Zimnya, I. A. (2006). Competence approach: What is its place in the modern approaches to education? Journal of Higher education today, 8, 29.

Zyalaeva, R. G., Matukhin, E. L., Safin, R. S., \& Shaidullina, A. R. (2012). Formation and development of innovative entrepreneurship education in secondary and higher vocational school of Russia: Scientific and methodical manual (p. 84). Kazan Publisher "School".

\section{Copyrights}

Copyright for this article is retained by the author(s), with first publication rights granted to the journal. This is an open-access article distributed under the terms and conditions of the Creative Commons Attribution license (http://creativecommons.org/licenses/by/3.0/). 